\title{
Influence of Insecurity of School Environment on the Behaviour of Secondary School Students in Isiala-Ngwa North and South Local Government Areas of Abia State, Nigeria
}

\author{
Ojukwu, M. O. (Corresponding author) \\ Michael Okpara University of Agriculture, Umudike, Nigeria \\ E-mail: floxymark2008@yahoo.com \\ Nwanma Ahaoma Chigozirim \\ Michael Okpara University of Agriculture, Umudike, Nigeria \\ E-mail: oluahaoman@gmail.com
}

Received: 10-10- 2015

doi:10.7575/aiac.ijels.v.3n.4p.49
Accepted: $28-10-2015$

URL: http://dx.doi.org/10.7575/aiac.ijels.v.3n.4p.49

Published: $31-10-2015$

\begin{abstract}
This study examined the influence of insecurity of school environment on the behavior of secondary school students. A total of 200 students responded to a self-structured validated questionnaire designed for the study. Three hypotheses were formulated to guide the study. Independent samples t-tests were used in analysing the data. The findings revealed that Isiala-Ngwa North and South Local Government Areas were significantly different $(p<.001)$ with regard to the insecurity of their schools, with northern schools having a higher rate of school insecurity. Furthermore, the analysis of data revealed no significant difference $(p>.05)$ between the insecurity of private and public schools although private schools turned out to be slightly more insecure. Finally, no significant difference $(p>.05)$ was found between male and female students' behaviour due to school environment insecurity. It is recommended that the government should strengthen and motivate its supervisory unit in the ministry of education to enable them carry effective supervision and monitoring of the state secondary schools.
\end{abstract}

Keywords: insecurity, school environment, students' behaviour, environment

\section{Introduction}

The concept of education has been discussed at different fora, settings of knowledge and has been defined by several schools of thought and scholars. Osaat (2012) posited that education can be viewed as a process of developing and transmitting the culture of a people from generation towards achieving the goal of good life and behaviour in an individual. This suggests that education is the vehicle upon which cultural and moral values are transmitted from old people to the young. Nwanna-Nzewunwa (2009) defined education as an institution which creates an environment that prepares the mind to develop the right personality, equips the individual with knowledge, skills and values of the past, so as to contribute meaningfully at present and in future.

Education transforms the human being from a raw material state into a finished product whereby man can function effectively and efficiently, physically, mentally, socially, emotionally, culturally and technologically (Osaat, 2012). These noble goals of education can never be achieved in a vacuum. These goals would be achieved in a conducive and peaceful school environment (Lehr, 2004).

Considering various challenging experiences in the present day Nigeria, there seems to be a gap or difference between the goals of education and what educational institutions can achieve through positive environment as when compared to their essence of establishment. In accessing the most vulnerable of insecurity in our society, Nwanna-Nzewunwa (2009) argued that women and children are the most victims. These children who might be of secondary school age fall to the stage of transition between childhood and adulthood when patterns of behaviour and relationship begin to take proper shape in life. According to Amachukwu (2014), the broad objectives for the establishment of secondary education is to prepare all primary school learners with the opportunity of education of a higher level, irrespective of sex, social status, religion or ethnic background, offer diversified curriculum to cater for the difference in talents, opportunities and future roles etc.

However, the greatest question still not answered by educationists, psychologists and other scholars is how we can achieve laudable objectives of secondary school education considering the high state of insecurity of our school environment. Security in simple terms means protection of lives and properties from destruction. Onifode, Imhonopi and Urrim (2013) posited that security is a dynamic condition which involves the relative ability of a state to counter threats to its core values and interest and that the primary beneficiaries are the citizens. In addition, sharing the view of Abraham Maslow, Iyenger (1977) stated that an insecure person perceives the world as a life threatening jungle; feels unsafe, unhappy, rejected, hostile, and pessimistic; shows sign of tension, conflict, and guilt; and tends to be neurotic 
and generally egocentric. Therefore, it seems that when a student studies in an environment that is characterized by insecurity, the student is bond to suffer socially, mentally and emotionally and it makes sense to add that all these are bound to affect the student behaviour.

A school environment characterized by insecurity is likely to suffer the following: its classroom, hostels, laboratories and refectories being always in dilapidated conditions, the teachers having negative attitude to condone and accept the emotional needs of students and there would be undue influences and clashes, of a local community interfering with school business. Others include that the psychological problems of the students are never met or carelessly handled, there are segregations in the school community along religious, tribal and sectarian lines, students ignore teachers' directives and challenges the teacher on certain concepts and school properties are deliberately damaged by students to show their disapproval of management's decision.

In addition, lateness is a norm in school, while students are allowed to freely use handsets and phones. Annually, the external results of the school are always bad as a result of poor teaching climate of the school; for example, the 2015 Senior School Certificate Examination (SSCE) result by West African Examinations Council (WAEC) in Chemistry showed that out of 126, 401 candidates that sat for the subject in all Abia State Secondary Schools, only 26,031 were able to credit Chemistry. This means that for university admission only 26,031 in that year would use Chemistry as one of the subjects that would qualify them for university admission. Other instances of insecurity of the school environment include that sometimes female staff and students complain of being raped or impregnated leading to school dropout. Also, parents complain that their children are bullied and injured, and the classrooms are overcrowded, poorly ventilated and lit (Ghazi, Shahzada, Tariq, \& Khan, 2013). The above painted school environment will no doubt affect the students' behaviour.

School environment connotes all human and materials resources available in the school in which a child can see, hear, touch, smell, taste, feel and respond to (Obi, Johnson \& Lawani, 2004). Miller and Cunnighan (2011) argued that the issue of school environment is multi - dimensional. It possesses the physical, social, and academic dimensions. The physical dimension includes, the appearance of school building and classrooms, libraries, laboratories, hostels, sporting, games and recreational facilities. Others are instructional materials, school size and ratio of student - teacher in the classroom. Also included are the order and organization of classrooms in the school, the position of chalk or whiteboard and the availability of resources to afford safety and comfort. The social dimension include, the quality of inter personal relationship between and amongst students, teachers, and administrators, equitable and fair treatment of students by teachers and staff, the degrees of competition and social comparison amongst students and the degree to which students and teachers contribute to the decision making process of the school. The academic dimension includes the quality of instruction given to students and the teacher's expectations for good achievements from students (Miller \& Cunnighan, 2011). Hypothetically the above environment will have a positive impact on the bahaviour of students in the school.

In Canada, Ontario Ministry of Education (2009) identified the following as the characteristics of a safe school environment, a caring and cooperative place where sound positive relationships abound between students and staff. Where there is respect for democratic values, rights and responsibilities and where there is respect for cultural diversity. In addition, there is respect for law and order as well as respect for individual differences. Also there are clear, consistent and appropriate behavioural expectations and positive role modelling for staff and students.

The levels at which these variables can positively interact with each other in the school environment usually help to make teaching and learning, which may affect students behaviour. The end result is that it brings effectiveness in the classroom, enhances student cooperation and affects his behaviour, promotes sharing of love and efficient planning by school authorities.

The school primarily should be a place where norms, cultural values, national unity, national consciousness and other appropriate entrepreneurial skills are transmitted by the teacher to the students in a regulated manner (Osaat, 2012). It should be a positive character molding factory and the safest place next to the home of any child (Fareo, 2015). The enabling learning environment created in a school should be a rallying point where those from peaceful and dysfunctional homes, children living in poverty, children of teenage parents and all those who are disadvantaged come to interact with different dimensions of knowledge (Fareo, 2015; Hurwitz, Menaucer \& Weldon, 1996). Unfortunately, there seems to be a paradigm shift in the basic roles of the school as a transforming agent of the society as a result of the insecurity of the school environment.

The school is currently confronted with the problems of students possessing dangerous weapons that can be used to easily perpetrate evil acts. Others are involved in gang recruitment and rivalry, drug trafficking, murder, rape and other criminal behaviours (Fareo, 2015). Some of these problems have led to violent acts in and around the school environment, thereby making school culture to become toxic in nature. Madison (2015) is of the view that in a toxic school environment, the teacher-student, student-student, staff-staff relationships are always conflicting and devoid of commitment for excellence. Such toxic learning environment lack sense of purpose, have norms that reinforce inertia, blame students for lack of progress and often have actively hostile relations.

Fayeye (1999) posited that adolescent personality behaviours can be developed through dynamic orientation of the environment and social interaction. The implication of this view remains the fact that the school being an enclosed 
social environment has a lot to do with adolescent or secondary school students' behaviour patterns when the school environment is insecure. All patterns of behaviours, including deviance, are learned from the environment and particular behaviour learned at the earliest years are critical to one's personality development. He further stated that behaviour to do good or bad can be motivated by situation and group interaction with peers, mischievous orientations, and disadvantaged background, inept desire to commit crime, boredom, depression, stress, strong feeling of inferiority complex and unfulfilled emotional needs (Fareo, 2015). Fayeye (1999) categorized the dimensions of behaviours which are developed from insecure school environment to include, conduct disorder, personality disorder, and inadequate immaturity and socialized delinquency.

According to Abdullahi, and Terhemba (2014), insecurity cases have been widely reported in many primary and secondary schools both within and outside the shores of Nigeria. Chilcot and Odgers (2009) revealed that the Education Minister of state of Queen land reported that most students exhibited combat violent behaviours, which accounted for nearly 55000 students being either suspended or expelled from school for various acts of misconduct in Australia between 2008 and 2009. Chilcott and Odgers (2009) further opined that some of the students were in the habit of fighting, others fought and injured fellow students, while some assaulted teachers and school principals. In Belgium, Bulgaria, France, Japan, Poland United States and South Africa it has been disclosed that there were numerous reports of hatred and teachers' raping of students in offices, students raping of peers, indecent and inappropriate dressing, aggressive punishments in classroom and hostels, Gay relationships, theft, bullying, rampant shooting of guns by minors to their friends in class and cultic initiations (Lucy, 2010; Galand, Lecocq \& Philipoh, 2007).

In Nigeria, Ekejiuba and Emetarom, (2014) reported that from 2000 to 2015, there have been more deaths and cases of missing students, teachers and other allied staff of schools across the country than since independence. There are several examples of insecurity of school environment cases that have been reported. One case includes the terrorist attack on $18^{\text {th }}$ December, 2011 of Nigeria Air Force School, Kano that was attacked by unknown gun men killing three Air Force Staff and injuring many students. In another case in 2012, 15 school children in a school bus were kidnapped on their way to school in Aba, Abia State. The kidnappers demanded twenty million Nigeria as ransom. Still another example was a teacher at a special education center in Adamawa State primary school raped by an under aged pupil (Ekejuba \& Emetarom, 2014).

The identified events and scenarios seem to have help to encourage negative behaviours, low academic performance, promote an outbreak of moral crisis, psychological trauma, anxiety, and fear frequently occurring daily amongst students in our school campuses. Because of the vulnerability of innocent students and the negative influence of insecurity of the school environment may have on their behaviour this study has become necessary. Therefore the focus of this study is to examine the influence of insecurity on the school environment on the behaviour of secondary school students in Isiala-Ngwa North and South Local Government Areas of Abia State of Nigeria.

\subsection{Statement of the Problem}

Since the inception of democracy in Nigeria in 1999, insecurity has become a major issue of concern to every citizen. On a daily basis the media has continued to highlight and discuss incessant cases of armed robbery, kidnappings, bombings, abductions, rape, cultic activities and a high rise in ethnic and communal clashes, which have become regular occurrences and have characterized life in Nigeria (Nwangwa, 2014). Media report are awash with the number of lives lost as a result of terrorist, insurgent and other attacks that seem to be alarming. As if some places in the country can be walled off from the negative impact of violence, our academic (schools) institutions have also become hot spots where cases of insecurity are recorded. The motivation and problem of study is to investigate the effect of the insecurity of school environment on the behaviour of secondary school students in Isiala-Ngwa North and South Local Government Areas of Abia State, Nigeria.

When the school environment is insecure, all patterns of behaviour including deviance are learned from the environment and the particular behaviours learned at the earliest years are critical to one's personality development. Also it has been noted that behaviour to do good or bad can be motivated by situation and group interaction with peers, mischievous orientations, disadvantaged backgrounds, inept desire to commit crime, boredom, depression, stress, strong feeling of inferiority complex and unfilled emotional needs.

In spite of the enormous amount of research that may have been devoted to the topic, truly scientific evidence about the influence of insecurity of school environment on the behaviour of secondary school students has been so little. To investigate this issues among others are also seen as the problems of this study.

\subsection{Objectives of the Study}

The objectives of the study were to:

1. Determine the statistical significance of the difference in the insecurity of school environment between IsialaNgwa North and South Local Government Areas of Abia State;

2. Determine the statistical significance of the difference between the environment insecurity of private and public secondary schools in Isiala-Ngwa North and South; and

3. Investigate the statistical significance of the difference between male and female students' behavior due to the insecurity of school environment in Isiala-Ngwa North and South. 
Insecurity of school environment does not significantly affect the behaviour of secondary school students in IsialaNgwa North and South.

$\mathrm{H}_{\mathrm{O} 1}$ : There is no significant difference in the insecurity of school environment between Isiala-Ngwa North and South Local Government Areas.

$\mathrm{H}_{\mathrm{O} 2}$ : There is no significant difference in the insecurity of the school environment between private and public secondary schools in Isiala-Ngwa North and South.

$\mathrm{H}_{\mathrm{O} 3}$ : There is no significant difference between male and female students' behavior due to the insecurity of school environment in Isiala-Ngwa North and South.

\section{Method}

The design of the study is survey. Nwankwo (2011) opines that descriptive survey aims at collecting data from a given sample of population and described probably certain features of the sample as well as generalize it to the entire population. This study is regarded as a descriptive survey as the researcher collected data from a large sample of students in ten senior secondary schools in Isiala-Ngwa North and South. It described how insecurity of school environments affected the behaviour of students in the area.

The target population of the study consisted of all the senior secondary school students in the ten secondary schools of the two Local government Areas of Isiala-Ngwa North and South of Abia State. The ten secondary schools have a population estimate of 2,000 students. The secondary schools are made up of public and private secondary schools. Four secondary schools were purposely selected from the ten because of the large population of students in the secondary schools.

The sample of the study consisted of $10 \%$ of the estimated population of 2,000 which is 200 students. Multistage random sampling technique was employed. The selection of students was done using stratified random sampling technique while simple random sampling was used to select four secondary schools, two each of public and private schools from the two Local Government Areas. Then, 50 students were simple randomly selected from each of the four secondary schools giving a total population of 200 made up of 100 females and 100 males.

The instrument for data collection was a self-designed questionnaire tagged "Influence of Insecurity of School Environment on Behaviour" (EISEB). The questionnaire used a 5-point Likert method of strongly agree, agree, undecided, disagree and strongly disagree. It had 3 sections. Section A included demographic questions. Section B comprised questions on insecurity and Section $\mathrm{C}$ was composed of questions on student behaviour. Copies of the questionnaire were given to experts in psychology and Measurement and Evaluation in the College of Education (Faculty) of Michael Okpara University of Agriculture, Umudike. Their criticisms and corrections were used to improve the face and content validity of the instrument.

The reliability of the instrument was determined using test-retest method and using Pearson Product Moment correlation. The correlation was $r=0.84$ (suggesting an agreement of $70.5 \%$ between the two tests) and was considered high to guarantee the use of the instrument for the study. With the use of Cronbach Alpha, the internal consistency of the scale yielded an acceptable value of 0.88 .

Copies of the instrument (EISEB) were self-administered by the researchers and were later collected for analysis. The EISEB questionnaire instrument was rated using the 5-point Likert scale of strongly agree (5 points), agree (4 points), undecided ( 3 points), disagree ( 2 points) and strongly disagree (1 point). The total score for each respondent was obtained by adding the scores obtained from each section, containing 15 items responded on a five point scale. The maximum score was 75 and the minimum score was 15 . Data obtained were analysed using t-test analyses.

\section{Results}

The results of the study are presented in this section.

\subsection{School environment insecurity in different geographical locations}

The first null hypothesis focused on the difference between Isiala-Ngwa North and South Local Government Areas in reference to the insecurity of their schools:

$H_{O I}$ : There is no significant difference in the insecurity of school environment between Isiala-Ngwa North and South Local Government Areas.

To test this null hypothesis, independent samples t-test was run, the results of which have been summarized in Table 1 .

Table 1. Insecurity of school environment between Isiala-Ngwa North and South

\begin{tabular}{lccccccc}
\hline School Location & $\mathrm{n}$ & $M$ & $S D$ & $\begin{array}{c}\text { Mean } \\
\text { difference }\end{array}$ & $t$ & df & $p$ \\
\hline North & 100 & 3.34 & .79 & .98 & 9.54 & 198 & .000 \\
South & 100 & 2.36 & .66 & & & \\
\hline
\end{tabular}


The t-test revealed a significant difference between the scores of respondents from Isiala-Ngwa North and South. Consequently, the null hypothesis was rejected; thus, it was concluded that there is a significant difference between insecurity of school environment between Isiala-Ngwa North and South with the Northern respondents feeling more insecure.

\subsection{Environment insecurity in different types of schools}

The second null hypothesis focused on the difference between private and public schools in reference to their environment insecurity:

$H_{O 2}$ : There is no significant difference in the insecurity of school environment between private and public secondary schools.

This hypothesis was tested using independent samples t-test (Table 2).

Table 2. Difference in the insecurity of school environment between private and public secondary schools

\begin{tabular}{lllllll}
\hline Type of school & $\mathrm{n}$ & $M$ & $S D$ & $t$ & $d f$ & $p$ \\
\hline Public & 100 & 3.343 & .876 & .172 & 198 & .863 \\
Private & 100 & 3.41 & .76 & & & \\
\hline
\end{tabular}

In testing this hypothesis, the respondents' scores on the measure of insecurity of school environment were subjected to test of difference using independent t-test.

Based on the results, $t(198)=0.172, p>.05$, there is no significant difference in the insecurity of school environment between private and public schools in Isiala-Ngwa North and South.

\subsection{School environment insecurity and male/female student behaviour}

The final null hypothesis examined the difference between male and female students' behaviour in response to the insecurity of their school environment:

$H_{O 3}$ : There is no significant difference between male and female students' behavior due to the insecurity of school environment in Isiala-Ngwa North and South.

This hypothesis was also tested using independent samples t-test (Table 3).

Table 3. Insecurity of school environment and students' gender

\begin{tabular}{lcccccc}
\hline Gender & $\mathrm{n}$ & $M$ & $S D$ & $t$ & $d f$ & $p$ \\
\hline Males & 100 & 3.38 & 0.56 & 1.78 & 198 & .077 \\
Females & 100 & 3.24 & 0.54 & & & \\
\hline
\end{tabular}

The results indicated that male students' behaviour $(M=3.38, S D=0.56)$ was affected slightly more than that of the female students $(M=3.24, S D=0.54)$ by the insecurity of school environment. However, the t-test results, $t(198)=$ $1.78, p>.05$, showed the insecurity of school environment will not lead to any significant differences between the behaviour of male and female students in Isiala-Ngwa North and South.

\section{Discussion}

The findings in this study revealed that insecurity of school environment significantly affects the behaviour of secondary school students. The result obtained is in line with Fayeye (1999) who reported that all patterns of behaviour including deviance are learned from the environment and that since the school is an enclosed social environment it follows that the school has a lot to do with adolescents behaviour patterns when the school environment is unsecured. This is not surprising because it has been stated that good or bad behaviour can be motivated by the environment, group interaction with peers, mischievous orientations, disadvantaged backgrounds, inept desire to commit crime, boredom, depression, stress, strong feeling of inferiority complex, and unfilled emotional needs (Fareo, 2015).

The results also showed that there was a significant difference between the insecurity of school environment in the Isiala-Ngwa North and South. This could be explained by the fact that schools located in Isiala-Ngwa South are in rural areas, which are indeed more secured while those in the North that lack facilities and are exposed to all the undesirable things that are associated with urban life.

The results further revealed that there is no significant difference in the insecurity of school environment between private and public schools as students in both private and government schools are students who chose the type of school they attend based on the expected freedom they wish to enjoy. Though this result showed no significant difference, government schools showed slightly more insecurity than private schools considering their mean results of 3.43 as against 3.41 for government and private schools respectively. The slight mean difference in the occurrence of insecurity 
of school environment between government and private secondary schools could be attributed to effective supervision. While the private schools would supervise and monitor their students, those in government secondary schools will receive little or no supervision and monitoring hence the higher mean score recorded by government owned secondary schools. This supports the view of Abdullahi and Terhemba (2004) who noted that the government's take-over of schools from the missions immediately after the Nigerian civil war has helped to stifle effective supervision and control of schools, thereby, creating opportunities for insecurity, attacks, violence, abandonment etc. Also, Amanchukwu (2014) and Nwangwa (2014) argued that these cases of insecurity of the school environment that are more prevalent in public schools result from lack of children's parental control, inequality of Nigerian society and government's inability to fulfil its promises to the electorate. Mudege, Elijah and Izugbara (2008) also opined that the high occurrence of these insecurity cases in our schools will worsen as African leaders fail to make education of school age children a major point of priority through the employment of qualified staff, provision of facilities and decent remuneration of staff.

Finally, the study showed that insecurity of the school environment has no significant effect on the behaviour of male and female students. Again though there is no significant difference, males' behaviour was more affected with the insecurity of school environment $(M=3.38)$ as against female $(M=3.25)$. Individual analysis of the items on the questionnaire indicated that more girls were involved in premarital sex, rape and suicidal attempts than the boys while more boys learnt drinking alcohol, bullying and kidnapping in school. Again girls usually suffered more from emotional trauma and depression due to failure than the boys and this affects their enrolment including sexual attacks by male teachers and fellow male students.

The findings of this study generally lend credence to the findings of Fayeye (1999) who categorized the dimensions of behaviours which were developed as a result of insecure school environment to include conduct disorder, personality disorder, inadequacy/immaturity and socialized delinquency. Conduct disorder is developed from an environment of physical, verbal aggression and inadequate interpersonal relations. Behaviours developed as a result of this include, fighting, bullying, temper tantrums, impatience, attention seeking, disruptiveness, wickedness and disobedience. Personality disorder is primarily caused by unmet students, emotional needs, feelings of inadequacy, and low achievements, which could lead into withdrawn social life. When this is the case students tend to suffer from depression, self-consciousness, shyness, fear, anxiety, feelings of inferiority complex, hyperactivity, defense mechanisms and shifting blames for mistakes made.

\section{Conclusion and Recommendation}

In conclusion, the results from this study have extended previous findings regarding influence of insecurity of school environment on behaviour. Behaviour of the Secondary School Students affected by the insecurity of the school environment. This is not surprising because it has been stated that good or bad behavior can be motivated by environment, group interaction with peers, mischievous orientations, disadvantaged backgrounds, and the like. Based on these, it is recommended that the government should strengthen its supervision unit in the ministry of education to enable it to carry out effective supervision and monitor its secondary schools to reduce students' negative behaviours. Also Government should employ qualified and efficient Guidance and Counsellors who will attend to the students' behavioural problems in the Secondary schools. This work examined insecurity of the school environment in both public and private schools using the same parameters. But, in Nigeria it appears that most private schools are better secured that the public schools.

No significant difference was found in the insecurity of the school environment in the public and private schools. This finding may be due to the fact that the nature of insecurity in public schools may not be the same as in private schools, because parents are paying high for both the academic and security of their children. This seems to be a good area for further research to be carried out in the area to determine the nature of insecurity prevalent in the private schools in the country.

\section{References}

Abdullahi, U and Terhemba, G. A. (2004). Influence of insecurity on Primary School Attendance in Damaturu Metropolis, Yobe State Nigeria. Journal of Research in Education and Society, 5(1) 33-38.

Amanchukwu, R. N. (2014). Management of Secondary Education for Sustainable Living in a Period of Security Challenges in Nigeria. Journal of Education and Practice, 5(19) 162-168.

Chilcott, T. and Odgers, R. (2009). Government can do more in School Violence. www.wikipedia.org

Ekejiuba, P. and Emetarom, U. (2014). Administration of Secondary Schools in Time of Insecurity in Nigeria: Problems and Prospects. Benin: University of Benin.

Fareo, D. O. (2015). Bullying in Nigeria Secondary School: Strategies for Counselling Intervention. http://www.ojjdp.ncjrs.org/ Retrieved 24/7/2015

Fayeye, J. O. (1999). Person - Situation Contingency and deviant Behaviour in Nigeria and Schools. International Journal of Business and Social Science, 6(1) 61-73. 
Galand, B. Lecocq, C. and Philipoh, P. (2007). School Violence and Teacher Professional Dissengement - Journal of Education Psychology, 77(21) 456 - 477.

Hurwitz, E. Menacker, J. and Weldon, W. (1996). Critical Issues: Developing and Maintaining Safe Schools http://www.ojjdp.ncrs.org/ Retrieved 26/7/2015

Inerhumwunwa, I. (2009). Formal Mentoring Initiative as a Likely Panacea to Students Maladaptive Behaviour http://www.ajol.inf/index.php/ejc/.../41260 Retrieved 26/7/2015

Lehr, C. A. (2004). Positive School Climate: Information for Education. National Association of School Psychologists - http://www.nasponline.org/.../schoolclimate_hopd... Retrieved 26/7/2015

Lucy, H. (2010). Hatred, Violence in our Schools' Classroom. www.wikipedia.org Retrieved 26/7/2015

Iyengar, B. K. S. (1977). Emotional Security. http://www.wikipediaonline.com Retrieved 30/7/2015

Masitsa, M. G. (2011). Exploring Safety in Township Secondary Schools in the Free State Providence. South Africa Journal of Education - http://www.scialo.org.za/scielo.php Retrieved 26/7/2015

Madison, W. (2015). Is Your School's Culture Toxic or Positive? www.education.com/a-adm/ Retrieved 29/7/2015

Miller, A. and Cunnigham, K. (2011). Classroom Environment. www.education.com/.../classroom Retrieved 30/7/2015

Mudege, N. N. Eliya, Z. M. and Izugbara, C. (2008). How Insecurity Impacts on School Attendance and School Dropout Among Urban Slum Children in Nairobi. International Journal of Conflict and Violence, 2(1) 98-112

Nwangwa, K. C. K. (2014). Controlling the Security Challenges in Nigeria. The Managerial Perspective. A Lecture Presented at the Distinguished Lecture/Management Luncheon Day for Institute of Management of Nigeria, Aba Chapter

Nelson, J. (2006). Operating in Insecure Environments. http://www.hks.harvard.edu/m-rcbg/CSRI/ Retrieved 26/7/2015

Nwankwo, O. C. (2011). A Practical Guide to Research Writing for Studies of Research Enterprise (4 ${ }^{\text {th }}$ Ed). Choba: Pam Unique Publishers.

Nwanna-Nzewunwa, O. P. (2009). Sociology of Education for Certificate and Diploma Students. PortHarcourt: Springfield Publishers Limited.

Ontario Ministry of Education (2009). Caring and Safe Schools in Ontario. www.edu.gov.on.ca/.../caring_safe Retrieved 30/7/2015

Obi, T. E. C., Johnson, H. I. and Lawani, C. (2014). The School Environment and the Child. Lagos: National Open University of Nigeria.

Osaat,S.D. (2012), Philosophy of Education; An Assessment $3^{\text {rd }}$ Ed. Portharcourt: SHAPEA Publishers Ltd.

Ghazi, S. R., Shahzada, G., Tariq, M., \& Khan, A. Q. (2013). Types and Causes of Students’ Disruptive Behavior in Classroom at Secondary Level in Khyber Pakhtunkhwa, Pakistan. American Journal of Educational Research, 1(9), 350-354. 